\title{
PENGARUH PENGETAHUAN ANGGOTA DEWAN TENTANG ANGGARAN DAN PERSEPSI ANGGOTA DEWAN TENTANG PARTISIPASI MASYARAKAT TERHADAP PENGAWASAN APBD DI KABUPATEN KLATEN
}

\author{
Rahmanti Arvitaningrum \\ Program Studi Akuntansi Fakultas Ekonomi Universitas Negeri Yogyakarta \\ rahmanti1997@gmail.com \\ Abdullah Taman \\ Staf pengajar Program Studi Akuntansi Universitas Negeri Yogyakarta \\ abtaman@uny.ac.id
}

\begin{abstract}
Abstrak: Pengaruh Pengetahuan Anggota Dewan Tentang Anggaran dan Persepsi Anggota Dewan tentang Partisipasi Masyarakat terhadap Pengawasan APBD di Kabupaten Klaten. Penelitian ini bertujuan untuk mengetahui pengaruh Pengetahuan Anggota Dewan Tentang Anggaran dan Persepsi Anggota Dewan tentang Partisipasi Masyarakat terhadap Pengawasan APBD di Kabupaten Klaten. Penelitian ini merupakan jenis penelitian kuantitatif. Populasi dalam penelitian ini adalah anggota DPRD Kabupaten Klaten yang berjumlah 50 orang. Teknik pengambilan sampel dengan metode sampel jenuh. Teknik pengumpulan data menggunakan kuesioner yang telah diuji validitas dan reliabilitasnya. Teknik analisis data menggunakan regresi linear sederhana dan regresi linear berganda. Hasil penelitian ini menunjukkan bahwa: (1) Pengetahuan Anggota Dewan tentang Anggaran berpengaruh positif dan signifikan terhadap Pengawasan APBD, (2) Persepsi Anggota Dewan tentang Partisipasi Masyarakat berpengaruh positif dan signifikan terhadap Pengawasan APBD, dan (3) Pengetahuan Anggota Dewan tentang Anggaran dan Persepsi Anggota Dewan tentang Partisipasi Masyarakat berpengaruh terhadap Pengawasan APBD.
\end{abstract}

Kata kunci: Pengetahuan Anggota Dewan tentang Anggaran, Persepsi Anggota Dewan tentang Partisipasi Masyarakat, dan Pengawasan APBD

Abstract: The Effect of Board Members Knowledge about Budget and the Perception of Board Members about Community Participation in the Supervision of the Budget in Klaten Regency. This study aims to analyze the influence of Board Member Knowledge and Perception of Board Members on Community Participation in Regional Budget Monitoring in Klaten Regency. This research is a quantitative research. The population in this study were 50 members of the Klaten Regency DPRD. The sampling technique is using the saturated sample method. Data collection techniques is conducted by using questionnaires that have been tested for validity and reliability. The data analysis technique uses multiple linear regression. The results of this study indicate that: (1) The Board's Knowledge of the Budget has a positive and significant effect on the APBD Supervision, (2) Perception of Board Members on Community Participation has a positive and significant effect on APBD Supervision, and (3) Board Knowledge of the Budget and Perception of Board Members on Community Participation affect the $A P B D$ Supervision.

Keywords: Knowledge of Board Members, Perception of Board Members on Community Participation, and Regional Budget Monitoring 


\section{PENDAHULUAN}

Pemerintah adalah suatu organisasi yang diberi kekuasaan untuk mengatur kepentingan Bangsa dan Negara. Lembaga pemerintah dibentuk umumnya untuk menjalankan aktivitas layanan terhadap masyarakat. Tujuan yang ingin dicapai biasanya ditentukan dalam bentuk kualitatif, misalnya peningkatan keamanan dan kenyamanan, mutu pendidikan, mutu kesehatan dan keimanan.

Menurut Peraturan Pemerintah (PP) Nomor 58 tahun 2005 Tentang Pengelolaan dan Pertanggungjawaban Anggaran menjelaskan bahwa: 1)Pengawasan atas anggaran dilakukan oleh dewan, (2) Dewan berwenang memerintahkan pemeriksa eksternal di daerah untuk melakukan pemeriksaan terhadap pengelolaan anggaran. Menurut penjelasan di atas, salah satu aspek penting dalam rangka pelaksanaan otonomi daerah dan desentralisasi adalah masalah keuangan dan anggaran daerah (APBD). Oleh karena itu, diperlukan peranan anggota DPRD yang sangat besar untuk mengontrol kebijakan keuangan daerah (APBD) yang ekonomis, efesien, efektif, transparan, dan akuntanbel.

Dan berdasarkan UU Nomor 32 Tahun 2004 pasal 41, lembaga legislatif mempunyai tiga fungsi yaitu:

1. fungsi legislasi (fungsi membuat peraturan perundang-undangan).
2. fungsi anggaran (fungsi menyusun anggaran).

3. fungsi pengawasan (fungsi untuk mengawasi kinerja eksekutif).

Sedangkan di sisi lain, otonomi yang luas, nyata, bertanggungjawab membawa perubahan pada pola dan sistem pengawasan dan pemeriksaan. Perubahan pada pola pengawasan terkait dengan diberinya keleluasaan kepada pemerintahan daerah untuk mengatur dan mengurus rumah tangganya sendiri, maka diperlukan manajemen keuangan daerah yang mampu mengontrol kebijakan keuangan daerah secara ekonomis, efisien, efektif, transparan, dan akuntabel (Devi, 2010).

Pengawasan keuangan daerah adalah segala tindakan untuk menjamin agar pengelolaan keuangan daerah berlangsung sesuai dengan rencana, aturan-aturan dan tujuan yang telah ditetapkan. Menurut Undang-undang Nomor 32 Tahun 2004 tentang Pemerintah Daerah pasal 42 ayat 1C menjelaskan bahwa "DPRD mempunyai tugas dan wewenang melaksanakan pengawasan terhadap pelaksanaan Perda dan peraturan perundang-undangan lainnya, peraturan kepala daerah, APBD, kebijakan pemerintah dalam melaksanakan program pembangunan daerah dan kerjasama internasional di daerah". Berdasarkan dari Undang-undang tersebut dapat diambil kesimpulan bahwa pengawasan keuangan 
daerah dilakukan oleh DPRD yang berfokus kepada pengawasan terhadap pelaksanaan APBD. Pengawasan terhadap pelaksanaan APBD wujudnya adalah dengan melihat, mendengar, dan mencermati pelaksanaan APBD yang dilakukan oleh SKPD, baik secara langsung maupun berdasarkan informasi yang diberikan oleh konstituen, tanpa masuk ke ranah pengawasan yang bersifat teknis.

Pengawasan APBD adalah segala kegiatan untuk menjamin agar pengumpulan pendapatan-pendapatan daerah, dan pembelanjaan pengeluranpengeluaran daerah berjalan sesuai dengan rencana, aturan-aturan dan tujuan yang telah ditetapkan. Pengawasan sebagian besar berkaitan dengan pengawasan anggaran, namun pengawasan sesungguhnya merupakan bagian yang penting dari pengurusan keuangan secara keseluruhan, maka pengawasan meliputi mulai sejak tahap penyusunan dan berakhir pada tahap pertanggungjawaban. Secara umum pengawasan merupakan segala kegiatan dan tindakan untuk menjamin agar pelaksanaan suatu kegiatan berjalan sesuai dengan rencana, aturan-aturan dan tujuan yang telah ditetapkan.

Kinerja dewan dalam menjalankan fungsi pengawasan (fungsi mengawasi atas pelaksanaan peraturan daerah dan pelaksanaan APBD) selalu menjadi perhatian khusus. Hal ini dikarenakan
DPRD merupakan wakil rakyat yang mengemban amanah dari rakyat yang diharapkan mampu untuk menjalankan amanah tersebut supaya terbebas dari pelanggaran-pelanggaran dan penyelewengan anggaran sehingga dapat mensejahterakan masyarakat. Namun kepercayaan masyarakat terhadap kinerja dewan cenderung menurun dikarenakan maraknya kasus penyelewengan dan kebocoran anggaran akhir-akhir ini yang menandakan kinerja dewan yang belum optimal.

Kasus yang belum lama terjadi adalah Badan Pemeriksa Keuangan dan Pembangunan (BPKP) Provinsi Jawa Tengah menemukan sejumlah pelanggaran dimulai dari pengesahan hingga penggunaan APBD di Kabupaten Klaten. Dari hasil pengamatan dan evaluasi, BPKP menemukan sejumlah pelanggaran pada penyusunan APBD khusus untuk tahun 2014 lalu. Pertama, Rancangan Kebijakan Umum APBD Prioritas dan Plafon Anggaran Sementara (KUA PPAS) disepakati oleh Kepala Daerah dan DPRD seharusnya bulan Juli, namun tahun 2014 disepakati pada tanggal 12 Desember. Kedua, penyusunan KUA PPAS yang telah disepakati oleh Pemerintah Daerah (Pemda) dan DPRD belum sepenuhnya berdasarkan Rencana Kerja Pemerintah Daerah (RKPD). Ketiga, penyusunan indikator kinerja target program dan 


\section{JURNAL NOMINAL / VOLUME VIII NOMOR 2 / TAHUN 2019}

kegiatan pada APBD tidak spesifik, hanya berupa persentase paket kegiatan tahun berjalan sehingga tidak terukur. Selanjutnya, pengesahan APBD terlambat dari jadwal yang ditetapkan UndangUndang, yakni paling lambat 31 Desember setiap tahunnya. Namun, pada tahun 2014 Kabupaten Klaten menetapkannya pada tanggal 8 Februari.

Dengan adanya kasus tersebut, fungsi pengawasan dewan dipertanyakan. Kemana fungsi pengawasan dewan? Mengapa pelanggaran-pelanggaran seperti yang dilansir oleh BPK tidak terdeteksi oleh dewan? Untuk meminimalisir pelanggaran dan penyimpangan yang terjadi seperti kasus yang telah dipaparkan di atas fungsi pengawasan dewan sangat dibutuhkan. Dalam menjalankan fungsi pengawasannya, anggota dewan sangat dipengaruhi oleh pengetahuan anggaran yang dimilikinya untuk dapat mendeteksi setiap pelanggaran dan penyelewengan anggaran yang terjadi. Selain itu, dengan memiliki pengetahuan anggaran yang tinggi akan sangat membantu seseorang dalam memecahkan persoalan yang dihadapinya sesuai dengan kedudukan anggota DPRD sebagai wakil rakyat.

Lemahnya pengawasan APBD disebabkan sebagian besar anggota DPRD terkesan pragmatis dan cenderung lebih mengikuti kepentingan partai daripada berorientasi kepada rakyat. Seiring dengan periode ini anggota dewan mulai didominasi oleh wajah baru, yang dipilih dan diangkat dari partai-partai pemenang pemilu yang mempunyai latar belakang pendidikan dan pekerjaan yang berbedabeda sebelum menjadi anggota DPRD. Sehingga ketika mereka dipilih menjadi anggota dewan, keterbatasan pengetahuan dan utamanya pengalaman tentunya akan menjadi kendala dalam melaksanakan fungsi pengawasan yang baik. implikasi dari kondisi tersebut menyebabkan terjadinya permasalahan dan kelemahan dalam pengelolaan keuangan daerah dari aspek lembaga legislatif yaitu masih rendahnya peran DPRD dalam keseluruhan proses atau siklus anggaran mulai dari perencanaan, pelaksanaan, pelaporan hingga pengawasan program kerja eksekutif (Winarna dan Murni, 2007). Hal tersebut bisa dijadikan contoh dari La Palombara dalam Winarna dan Murni (2007) yang menyatakan ada beberapa faktor yang mempengaruhi sikap, perilaku, dan peran legislatif yaitu institusi politik, partai politik, karakteristik personal, pengalaman politik dan sifat pemilih. Oleh karena itu hal tersebut telah membuka peluang yang sangat luas untuk memberdayakan masyarakat, menumbuhkan prakarsa dan kreativitas, meningkatkan peran serta masyarakat, sekaligus mengembangkan peran dan fungsi DPRD. 
Berdasarkan penjelasan di atas lemahnya fungsi pengawasan legislatif merupakan faktor yang mempengaruhi kinerja legislatif terhadap eksekutif. Pengawasan keuangan daerah (APBD) yang dilakukan oleh dewan dipengaruhi oleh sistem dan individu secara pribadi (Sastroatmodjo, 1995 dalam Winarna dan Murni, 2007). Permasalahan tersebut apabila dikaji ada dua tingkat orientasi politik yang mempengaruhi perilaku politik, yaitu permasalahan berdasarkan sistem dan permasalahan akibat dari individu. Kelemahan yang terjadi atas peranan legislatif dalam pengawasan keuangan daerah dapat mungkin terjadi karena kelemahan sistem politiknya ataupun individu sebagai pelaku politik. Oleh karena itu, untuk menjelaskan perilaku suatu lembaga dalam hal ini DPRD yang perlu ditelaah bukan lembaganya, melainkan latar belakang individu yang secara aktual mengendalikan lembaganya, dalam artian perannya sebagai seorang wakil rakyat, apakah sesuai dengan yang diharapkan atau tidak.

Ada dua aspek yang diperlukan agar pengawasan yang dilakukan oleh anggota dewan, yaitu internal control dan eksternal control yang baik serta dapat dipertanggungjawabkan. Faktor internal adalah faktor yang dimiliki oleh dewan yang berpengaruh secara langsung terhadap pengawasan yang dilakukan oleh dewan, salah satunya adalah pengetahuan tentang anggaran. Sedangkan faktor eksternal adalah pengaruh dari luar terhadap fungsi pengawasan oleh dewan yang berpengaruh secara tidak langsung terhadap pengawasan yang dilakukan oleh dewan, diantaranya adalah adanya partisipasi masyarakat. Sehubungan dengan hal tersebut berjalan dengan mekanisme yang semestinya maka peran atau kinerja dari dewan menjadi semakin meningkat dalam mengontrol atau melakukan pengawasan terhadap kebijaksanaan pemerintah.

Faktor pertama yang mempengaruhi pengawasan APBD adalah pengetahuan anggota dewan tentang anggaran. Pengetahuan yang dibutuhkan dalam melakukan pengawasan keuangan daerah salah satunya adalah pengetahuan tentang anggaran, karena dengan mengetahui anggaran maka diharapkan seluruh anggota dewan dapat mendeteksi adanya pemborosan dan kebocoran tentang anggaran. Keterlibatan rakyat tersebut sangat diperlukan untuk mengakomodasikan kepentingan mereka dalam proses penyusunan rencana pembangunan. Hal ini didasarkan pada pemikiran bahwa rakyat baik secara individu maupun kelompok adalah pihakpihak yang berkepentingan dengan kegiatan dan hasil pembangunan, baik sebagai penanggung biaya, pelaku, penerima manfaat maupun penanggung 
resiko, sehingga dengan terbukanya keterlibatan masyarakat dalam pembangunan nasional tersebut maka rakyat bukan hanya sekedar pemberi amanat, tetapi juga harus terlibat aktif dalam setiap proses pembangunan nasional, termasuk dalam pengelolaan keuangan baik itu di pusat maupun dikabupaten/kota/provinsi, mulai dari tahap perencanaan sampai kepada pengawasan.

Yudhoyono (2000) menyatakan bahwa DPRD akan dapat memainkan peranannya dengan baik apabila pimpinan dan anggotaanggotanya berada dalam kualifikasi ideal, dalam arti memahami benar hak, tugas, dan wewenangnya dan mampu mengaplikasikannya secara baik, dan didukung dengan tingkat pendidikan dan pengalaman di bidang politik dan pemerintahan yang memadai (Jaka Winarna dan Sri Murni, 2007). Kinerja dewan dalam menjalankan fungsi legislatif selalu menjadi perhatian khusus masyarakat karena dipercayakannya amanah pada anggota dewan untuk dapat mensejahterakan masyarakat. Akan tetapi, kepercayaan tersebut, sekarang ini cenderung berkurang bahkan banyak yang tidak mempercayai kinerja dewan. Hal ini disebabkan kinerja dewan yang belum optimal dan belum mempunyai komitmen yang kuat dari para anggota dewan. Sikap yang muncul ini memotivasi peneliti untuk melakukan penelitian ini.
Salah satu kasus terkait rendahnya pengetahuan anggota dewan tentang anggaran terjadi di Klaten. Anggota dewan Klaten dalam menyusun anggarannya belum berdasarkan skala prioritas, biaya honor tanpa mempertimbangkan azas kepatuhan, kewajaran dan rasionalitas dalam pencapaian sasaran program dan kegiatan, dan penganggaran belanja modal tidak didukung dengan rencana kebutuhan barang. Sedangkan hasil pengamatan penggunaan dana hibah bansos (bantuan sosial) di Kabupaten Klaten, peraturan Kepala Daerah tentang bansos/hibah belum mengakomodir Peraturan Menteri Dalam Negeri (Permendagri) Nomor 39 Tahun 2012 tentang perubahan Permendagri Nomor 32 Tahun 2011 tentang pedoman pemberian hibah dan bansos dari APBD. Mekanisme hibah 2014-2015 juga tidak sesuai dengan peraturan perundangundangan yang berlaku karena berbagai alasan. Pertama, bansos atau hibah diberikan terus-menerus tiap tahun anggaran, kedua, Bupati tidak menetapkan daftar penerima hibah dan bansos. Ketiga, pemberian hibah dalam bentuk barang tidak didukung oleh naskah dan perjanjian hibah. Alasan lainnya, pemberian hibah uang belum dipertanggungjawabkan oleh penerimanya, alokasi anggaran bansos disalurkan ke partai, Pemberdayaan Kesejahteraan Keluarga (PKK) Kabupaten dan dharma wanita Kabupaten, serta 
belanja bansos diberikan ke kelompok masyarakat yang bukan berasal dari Kabupaten Klaten (KabarKlaten, Kamis, 29 Oktober 2015).

Selain pengetahuan anggota dewan tentang anggaran, faktor yang berpengaruh terhadap pengawasan APBD adalah partisipasi masyarakat. Adanya keterlibatan masyarakat akan memperkuat proses penyelenggaraan pemerintah, maka peranan dewan dalam melakukan pengawasan keuangan daerah akan dipengaruhi oleh keterlibatan masyarakat dalam proses penganggaran. Partisipasi masyarakat dalam penganggaran harus dilakukan pada setiap tahapan dalam siklus anggaran mulai dari penyusunan, ratifikasi, pelaksanaan, sampai dengan pertanggungjawaban (Mardiasmo, 2002; 70). Selain partisipasi masyarakat dalam proses APBD, prinsip-prinsip lain dalam penyusunan anggaran seperti transparansi dan akuntanbilitas, disiplin anggaran, keadilan anggaran, efesiensi, efektifitas serta taat azas yang harus diperhatikan.

Partisipasi masyarakat dalam penganggaran harus dilakukan pada setiap tahapan dalam siklus anggaran mulai dari penyusunan, ratifikasi, pelaksanaan, sampai dengan pertanggungjawaban (Mardiasmo, 2002; 70). Fakta di lapangan berdasarkan hasil penelitian Sopanah (2003) partisipasi masyarakat dalam penyusunan APBD masih sangat kecil bahkan hampir tidak ada, padahal partisipasi masyarakat akan memperkuat pengawasan yang dilakukan oleh DPRD (Sopanah, 2009). Artinya problem nyata yang dihadapi adalah mekanisme partisipasi tidak memberikan ruang apresiatif dari masyarakat karena patisipasi yang dijalankan hanyalah partisipasi yang cenderung semu, simbolis penuh dengan manipulasi karena aturan-aturan yang tidak bisa menjamin proses penganggaran, berdasarkan people need assessment (Sopanah, 2009).

Pada kenyataannya anggota dewan di Kabupaten Klaten memiliki persepsi negative pada partisipasi masyarakat dalam penyusunan anggaran. Anggota dewan menganggap partisipasi masyarakat bukanlah hal utama dalam penyusunan APBD. Hal ini dikarenakan meskipun penyusunan anggaran dibahas secara formal, terbuka, dan dikawal media, namun pada saat finishing rakyat tidak pernah dilibatkan dalam proses penyusunan anggaran (KLATEN, suaramerdeka.com). Bahkan dalam surat kabar Kompas (2015) mantan Ketua DPR, Marzuki Alie pernah menyatakan "rakyat biasa jangan diajak membahas pembangunan gedung baru, hanya orang-orang elit, orang-orang pintar yang bisa diajak membicarakan masalah itu". Pernyataan sang mantan pimpinan lembaga legislatif ini sangat ironi karena memiliki persepsi negative pada partisipasi 


\section{JURNAL NOMINAL / VOLUME VIII NOMOR 2 / TAHUN 2019}

masyarakat

(https://www.kompasiana.com/).

Kasus lainnya yang terjadi di Klaten. Belum lama ini Kabupaten Klaten diminta untuk mengembalikan kelebihan bayar penghasilan DPRD sebesar Rp 2,5 miliar. Dana dari APBD 2017 yang sudah telanjur diterima itu harus dikembalikan sebab salah hitung. Ketua DPRD Kabupaten Klaten, Agus Riyanto mengatakan kewajiban pengembalian itu tertuang sebagai salah satu rekomendasi Badan Pemeriksa Keuangan RI (BPK-RI) setelah ada audit pemeriksaan laporan keuangan Kabupaten Klaten tahun $2017 \quad$ (Klaten, suaramerdeka.com). Berdasarkan Studi Fenomenologis tentang Menguak Partisipasi Masyarakat Dalam Proses Penyusunan APBD (Sopanah, 2010;4), bahwa mekanisme partisipasi tidak memberikan ruang apresiatif dari masyarakat karena patisipasi yang dijalankan hanyalah partisipasi yang cenderung semu, simbolis penuh dengan manipulasi karena aturan-aturan yang tidak bisa menjamin proses penganggaran.

Penelitian juga diharapkan dapat mengetahui seberapa besar persepsi anggota dewan tentang partisipasi masyarakat dan pengetahuan dewan tentang anggaran mempengaruhi pengawasan keuangan daerah (APBD) khususnya di Kabupaten Klaten Jawa Tengah. Dari uraian di atas maka penelitian ini mengambil judul: "Pengaruh Pengetahuan Anggota Dewan Tentang Anggaran Dan Persepsi Anggota Dewan Tentang Partisipasi Masyarakat Terhadap Pengawasan APBD Di Kabupaten Klaten”.

\section{KAJIAN LITERATUR}

Yudhoyono (2002) menyatakan bahwa DPRD akan mampu menggunakan hakhaknya secara tepat, melaksanakan tugas dan kewajibannya secara efektif serta menempatkan kedudukannya secara proporsional jika setiap anggota mempunyai pengetahuan yang cukup dalam hal konsepsi teknis penyelenggaraan pemerintahan, kebijakan publik dan sebagainya. Pengetahuan yang akan dibutuh-kan dalam melakukan pengawasan keuangan daearah salah satunya adalah pengetahuan tentang anggaran.

Menurut Truman dalam Sopanah et al (2003) pengetahuan erat kaitannya dengan pendididkan dan pengalaman. Ketiganya mempengaruhi seseorang dalam melakukan suatu tindakan. Pengalaman dan pengetahuan yang tinggi akan sangat membantu seseorang dalam memecahkan persoalan yang dihadapinya sesuai dengan kedudukan anggota DPRD sebagai wakil rakyat. Seharusnya mereka adalah orang yang mempunyai pengetahuan dan pengalaman yang tinggi dalam bidang kemasyarakatan dan kenegaraan. 
Beberapa penelitian yang menguji hubungan antara kualitas anggota dewan dengan kinerjanya diantaranya dilakukan oleh (Indradi, 2001, Sutamoto, 2002). Hasil penelitiannya membuktikan bahwa kualitas dewan yang diukur dengan pendidikan, pengetahuan, pengalaman, dan keahlian berpengaruh terhadap kinerja dewan yang salah satunya adalah kinerja pada saat melakukan fungsi pengawasan. Pendidikan dan pelatihan berkaitan dengan pengetahuan untuk masa yang akan datang. $\mathrm{H}_{1}$ : Pengetahuan Anggota Dewan tentang anggaran berpengaruh terhadap pengawasan APBD.

Persepsi anggota dewan adalah Pemikiran anggota dewan yang memberikan sebuah pandangan tentang partisipasi masyarakat untuk ikut serta dalam penyusunan anggaran APBD.Tetapi dalam kenyataannya patisipasi yang dijalankan hanyalah partisipasi yang cenderung semu, simbolis penuh dengan manipulasi karena aturan-aturan yang tidak bisa menjamin proses penganggaran di Kabupaten Klaten.Dengan mengetahui tentang anggaran dan partisipasi masyarakat diharapkan anggota dewan dapat mendeteksi adanya pemborosan dan kebocoran anggaran.

Partisipasi masyarakat kunci sukses dalam pelaksanaan otonomi daerah karena dalam partisipasi yaitu menyangkut tentang aspek pengawasan dan aspirasi. Menyadari pentingnya aspirasi masyarakat, maka diperlukan langkah strategis agar partisipasi masyarakat bisa berjalan secara kondusif. Salah satu upaya yang bisa dilakukan adalah mengoptimalkan peran dari lembaga institusi lokal non pemerintahan seperti Lembaga Swadaya Masyarakat (LSM), media masa, organisasi kemasyarakatan dan partai politik. Selain pengetahuan anggota dewan, faktor yang berpengaruh positif signifikan terhadap pengawasan APBD adalah partisipasi masyarakat. Adanya keterlibatan masyarakat akan memperkuat proses penyelenggaraan pemerintah, maka peranan dewan dalam melakukan pengawasan keuangan daerah akan dipengaruhi oleh keterlibatan masyarakat dalam proses penganggaran.

Partisipasi berarti memberikan hak kepada masyarakat untuk memberi masukan dalam pembentukan prolegda, secara bersamaan mewajibkan Pemda dan DPRD mempermudah masukan/aspirasi tersebut sampai pada mereka.

\section{$\mathrm{H}_{2}$ : Persepsi Anggota Dewan tentang}

Partisipasi masyarakat berpengaruh terhadap pengawasan APBD.

Dengan mengetahui pengetahuan anggota dewan serta persepsi anggota dewan tentang partisipasi masyarakat diharapkan dapat meningkatkan pengaruh terhadap pengawasan APBD. Pengawasan merupakan tahap integral dengan 


\section{JURNAL NOMINAL / VOLUME VIII NOMOR 2 / TAHUN 2019}

keseluruhan tahap pada penyusunan dan pelaporan APBD. Pengawasan diperlukan pada setiap tahap bukan hanya pada tahap evaluasi saja (Mardiasmo, 2001). Pengawasan yang dilakukan oleh dewan dimulai pada saat proses penyusunan $\mathrm{APBD}$, pengesahan $\mathrm{APBD}$, pelaksanaan APBD, dan pertanggungjawaban APBD. Alamsyah (1997) menyebutkan bahwa tujuan adanya pengawasan APBD adalah untuk (1) menjaga agar anggaran yang disusun benar-benar dijalankan, (2) menjaga agar pelaksanaan APBD sesuai dengan anggaran yang telah digariskan, dan (3) menjaga agar hasil pelaksanaan APBD benar-benar dapat dipertanggungjawabkan. $\mathrm{H}_{3}$ : Pengetahuan Dewan tentang anggaran dan Persepsi Anggota Dewan tentang Partisipasi masyarakat berpengaruh terhadap pengawasan APBD.

\section{METODE PENELITIAN}

\section{Jenis Penelitian}

Penelitian ini merupakan jenis penelitian kuantitatif. Penelitian Kuantitatif diartikan sebagai metode penelitian yang berlandasan pada filsafat positivisme, digunakan untuk meneliti pada populasi atau sampel tertentu, pengumpulan data menggunakan instrumen penelitian, analisis data bersifat kuantitatif/ statisti, dengan tujuan untuk menguji hipotesis yang telah ditetapkan (Sugiyono, 2016).

\section{Tempat dan Waktu Penelitian}

Penelitian ini dilaksanakan di Kantor Pemerintah Daerah Kabupaten Klaten yang berlokasi di Jl. Pemuda Selatan No. 294, Klaten - Jawa Tengah. Waktu pelaksanaan penelitian pada bulan Februari hingga Maret 2019.

\section{Subjek Penelitian}

Populasi penelitian ini adalah seluruh anggota DPRD Kabupaten Klaten yang berjumlah 50 orang (dilihat dari profil kabupaten Klaten). Teknik pengambilan sampel pada penelitian ini menggunakan sampel jenuh karena seluruh anggota populasi dijadikan sebagai sampel penelitian. Hal ini sesuai dengan teori yang menyatakan bahwa apabila jumlah populasi kurang dari 100, lebih baik diambil semua, sehingga penelitiannya merupakan penelitian populasi (Arikunto, 2013: 112).

\section{Prosedur}

Metode pengumpulan data yang digunakan adalah data primer dan sekunder, untuk data primer berisi pertanyaan-pertanyaan yang ditunjukkan kepada responden, sedangkan untuk data sekunder penelitian ini berwujud catatancatatan terkait dengan variabel penelitian.

\section{Data, Instrumen, dan Teknik}

\section{Pengumpulan Data}

Data yang digunakan dalam penelitian ini adalah data primer dan sekunder. Teknik 
yang digunakan untuk mengumpulkan data pada penelitian ini menggunakan kuesioner. Instrumen penelitian yang digunakan dalam penelitian ini berupa angket tertutup, responden hanya memberikan checklist $(\sqrt{ })$ pada alternatif jawaban yang telah disediakan.

\section{Teknik Analisis Data}

Uji validitas dan uji reliabilitas dalam penelitian ini dilakukan pada sampel berjumlah 50 responden dari total populasi penelitian yang digunakan. Uji validitas dengan menggunakan korelasi Pearson Product Moment dan uji reliabilitas menggunakan Cronbach Alpha. Sedangkan hipotesis penelitian diolah menggunakan alat analisis regresi linear sederhana untuk mengetahui pengaruh secara parsial. Selain itu juga menggunakan regresi linear berganda untuk mengetahui pengaruh secara bersama-sama.

\section{HASIL PENELITIAN DAN \\ PEMBAHASAN}

\section{Hasil}

Hasil Uji Regresi Linear Sederhana untuk setiap hipotesis adalah:

Tabel 1. Hasil Regresi Linear Sederhana $\mathrm{H} 1$

\begin{tabular}{cccc}
\hline $\begin{array}{c}\text { Unstandarized } \\
\text { coefficient }\end{array}$ & T & Sig & Informasi \\
\hline 0,800 & 5,656 & 0,000 & $\begin{array}{c}\text { Hipotesis } \\
\text { Pertama } \\
\text { Diterima }\end{array}$ \\
\hline
\end{tabular}

Sumber: Data primer yang diolah, 2019

Berdasarkan tabel di atas, dapat dilihat bahwa nilai nilai $t_{\text {hitung }}$ adalah sebesar 5,656 jika dibandingkan dengan $t_{\text {tabel }}$ pada tingkat signifikansi 0,05, yaitu sebesar 2,009; maka

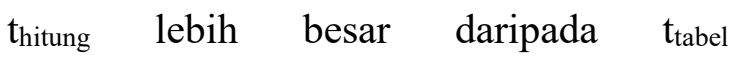
$(5,656>2,009)$. Nilai signifikansi sebesar 0,000 menunjukkan nilai yang lebih kecil dibandingkan dengan nilai pada tingkat signifikansi yang telah ditentukan sebelumnya, yaitu $0,05(0,000<0,05)$. Hasil uji hipotesis tersebut dapat disimpulkan bahwa variabel Pengetahuan Anggota Dewan tentang Anggaran berpengaruh positif dan signifikan terhadap Pengawasan APBD. Dengan demikian, hipotesis pertama yang menyatakan bahwa "Pengetahuan Anggota Dewan tentang Anggaran berpengaruh terhadap Pengawasan APBD" diterima.

Tabel 2. Hasil Regresi Linear Sederhana $\mathrm{H}_{2}$

\begin{tabular}{cccc}
\hline $\begin{array}{c}\text { Unstandarized } \\
\text { coefficient }\end{array}$ & T & Sig & Informasi \\
\hline 0,603 & 3,82 & 0,00 & $\begin{array}{c}\text { Hipotesis } \\
\text { Kedua } \\
\text { Diterima }\end{array}$ \\
\hline
\end{tabular}

Sumber: Data primer yang diolah, 2019

Berdasarkan tabel di atas, dapat dilihat bahwa nilai $t_{\text {hitung }}$ nilai $t_{\text {hitung }}$ adalah sebesar 3,824 jika dibandingkan dengan tabel pada tingkat signifikansi 0,05, yaitu sebesar 2,009; maka thitung lebih besar daripada $t_{\text {tabel }}$ $(3,824>2,009)$. Nilai signifikansi sebesar 0,000 menunjukkan nilai yang lebih kecil dibandingkan dengan nilai pada tingkat signifikansi yang telah ditentukan sebelumnya, yaitu $0,05(0,000<0,05)$. Hasil uji hipotesis tersebut dapat disimpulkan 


\section{JURNAL NOMINAL / VOLUME VIII NOMOR 2 / TAHUN 2019}

bahwa variabel Persepsi Anggota Dewan tentang Partisipasi Masyarakat berpengaruh positif dan signifikan terhadap Pengawasan APBD. Dengan demikian, hipotesis kedua yang menyatakan bahwa "Persepsi Anggota Dewan tentang Partisipasi Masyarakat berpengaruh terhadap Pengawasan APBD" diterima.

Tabel 3. Hasil Regresi Linear Berganda $\mathrm{H}_{3}$

\begin{tabular}{ccc}
\hline $\mathbf{F}$ & Sig & Informasi \\
\hline 23,290 & 0,000 & $\begin{array}{c}\text { Hipotesis Pertama } \\
\text { Diterima }\end{array}$
\end{tabular}

Sumber : Data primer yang diolah, 2019

Dari hasil pengujian diperoleh nilai $\mathrm{F}$ hitung sebesar 23,290 lebih besar dari $\mathrm{F}$ tabel sebesar 3,19 dengan signifikansi sebesar 0,000. Oleh karena nilai $F_{\text {hitung }}>F_{\text {tabel }}(23,290>3,19)$ dan signifikansi lebih kecil dari $0,05(0,000<0,05)$, maka dapat disimpulkan bahwa hipotesis ketiga yang menyatakan "Pengetahuan Anggota Dewan tentang Anggaran dan Persepsi Anggota Dewan tentang Partisipasi Masyarakat berpengaruh terhadap Pengawasan APBD" diterima. Selain itu, variabel Pengetahuan Anggota Dewan tentang Anggaran merupakan faktor dominan yang mempengaruhi Pengawasan APBD.

\section{Pembahasan}

Faktor pertama yang mempengaruhi Pengawasan APBD adalah Pengetahuan Anggota Dewan tentang Anggaran. Pengetahuan merupakan persepsi responden tentang anggaran
(RAPBD/APBD) dan deteksi terhadap pemborosan atau kegagalan, dan kebocoran anggaran (Panuntun.2012:11). Yudoyono (2000) menyatakan bahwa DPRD akan dapat memainkan peranannya dengan baik apabila pimpinan dan anggota-anggota nya berada dalam kualifikasi ideal, dalam arti memahami benar hak, tugas, dan wewenangnya dan mampu mengaplikasikan nya secara baik, dan didukung dengan tingkat pendidikan dan pengalaman di bidang politik dan pemerintahan yang memadai. Jadi pengetahuan anggota DPRD sangatlah berpengaruh untuk proses penyusunan anggaran.

Dalam menjalankan fungsi dan peran anggota dewan, kapasitas, dan profesi dewan sangat ditentukan oleh kemampuan bargaining position dalam memproduk sebuah kebijakan. Kapabilitas dan kemampuan dewan yang harus dimiliki antara lain pengetahuan, ketrampilan, dan pengalaman dalam menyusun berbagai peraturan daerah selain kepiawaian dewan dalam berpolitik mewakili konstituen dan kepentingan kelompok dan partainya. Pengetahuan diperoleh dari pendidikan dan pengalaman. Dimana pengetahuan akan memberikan kontribusi yang lebih baik apabila didukung pendidikan dan pengalaman yang memadai di bidang tugasnya. 


\section{JURNAL NOMINAL / VOLUME VIII NOMOR 2 / TAHUN 2019}

Pengetahuan anggaran juga dapat ditingkatkan melalui seminar-seminar, workshop-workshop, serta pelatihanpelatihan tentang pengelolaan dan pengawasan keuangan daerah. Namun, pendidikan yang tinggi belum tentu mengerti tentang anggaran, jadi harus diikuti dengan pengalaman pengalaman yaitu seperti mengikuti seminar tentang anggaran, lalu ada juga mengikuti tentang workshop yang bertema anggaran sektor publlik dan lain lain. Pengetahuan anggota DPRD tentang anggaran ini akan semakin penting apabila dikaitkan dengan mekanisme penyusunan dan penetapan APBD yang berlangsung saat ini.

Faktor kedua yang mempengaruhi Pengawasan APBD adalah Persepsi Anggota Dewan tentang Partisipasi Masyarakat. Partisipasi anggaran pada sektor publik terjadi ketika antara pihak eksekutif, legislatif dan masyarakat bekerja sama dalam pembuatan anggaran. Anggaran dibuat oleh kepala daerah melalui usulan dari unit-unit kerja yang disampaikan kepada kepala bagian dan diusulkan kepada kepala daerah, dan setelah itu bersama-sama DPRD menetapkan anggaran yang dibuat sesuai dengan Peraturan Daerah yang berlaku.

Achmadi dkk. (2002) menyebutkan bahwa partisipasi merupakan kunci sukses dari pelaksanaan otonomi daerah karena dalam partisipasi menyangkut aspek pengawasan dan aspirasi. Pengawasan yang dimaksud disini termasuk pengawasan terhadap pihak eksekutif melalui pihak legislatif. Semakin aktif masyarakat dalam proses penyelenggaraan pemerintahan akan berarti semakin sukses pelakasanaan otonomi daerah. Menyadari pentingnya aspirasi masyarakat, maka diperlukan langkah startegis agar partisipasi masyarakat bisa berjalan secara kondusif. Salah satu upaya yang bisa dilakukan adalah mengoptimalkan peran dari lembaga institusi lokal non pemerintahan seperti lembaga swadaya masyarakat (LSM), media masa, organisasi kemasyarakatan dan partai politik.

Partisipasi masyarakat kunci sukses dalam pelaksanaan otonomi daerah karena dalam partisipasi yaitu menyangkut tentang aspek pengawasan dan aspirasi. Adanya keterlibatan masyarakat akan memperkuat proses penyelenggaraan pemerintah, maka peranan dewan dalam melakukan pengawasan keuangan daerah akan dipengaruhi oleh keterlibatan masyarakat dalam proses penganggaran. Partisipasi masyarakat dalam penganggaran harus dilakukan pada setiap tahapan dalam siklus anggaran mulai dari penyusunan, ratifikasi, pelaksanaan, sampai dengan pertanggungjawaban. Dengan demikian dapat disimpulkan bahwa partisipasi masyarakat yang memadai mampu menunjang peningkatan pengawasan 
keuangan daerah. Semakin baik partisipasi masyarakat, maka semakin baik pula pengawasan keuangan daerah.

Pengawasan merupakan tahap integral dengan keseluruhan tahap pada penyusunan dan pelaporan APBD. Pengawasan diperlukan pada setiap tahap bukan hanya pada tahap evaluasi saja (Mardiasmo, 2001). Pengawasan yang dilakukan oleh dewan dimulai pada saat proses penyusunan $\mathrm{APBD}$, pengesahan $\mathrm{APBD}$, pelaksanaan APBD, dan pertanggungjawaban APBD. Pengawasan DPRD dapat dilakukan melalui beberapa mekanisme, yaitu rapat kerja, rapat dengar pendapat, rapat dengar pendapat umum, dan kunjungan kerja. Di samping itu, pengawasan dilakukan melalui penggunaan hak-hak DPRD, antara lain: hak interpelasi, hak angket, hak mengajukan/menganjurkan, memberikan persetujuan, memberikan pertimbangan, dan memberikan pendapat.

Hasil penelitian menunjukkan bahwa Pengawasan APBD dipengaruhi oleh Pengetahuan Anggota Dewan tentang Anggaran dan Persepsi Anggota Dewan tentang Partisipasi Masyarakat. Menurut Truman dalam Sopanah et al (2003) pengetahuan erat kaitannya dengan pendididkan dan pengalaman. Ketiganya mempengaruhi seseorang dalam melakukan suatu tindakan. Pengalaman dan pengetahuan yang tinggi akan sangat membantu seseorang dalam memecahkan persoalan yang dihadapinya sesuai dengan kedudukan anggota DPRD sebagai wakil rakyat. Seharusnya anggota DPRD adalah orang yang mempunyai pengetahuan dan pengalaman yang tinggi dalam bidang kemasyarakatan dan kenegaraan. Sementara itu, persepsi anggota dewan adalah pemikiran anggota dewan yang memberikan sebuah pandangan tentang partisipasi masyarakat untuk ikut serta dalam penyusunan anggaran APBD. Dengan demikian dapat disimpulkan bahwa adanya pengetahuan tentang anggaran dan partisipasi masyarakat diharapkan anggota dewan dapat mendeteksi adanya pemborosan dan kebocoran anggaran, sehingga dapat meningkatkan pengawasan APBD.

\section{SIMPULAN DAN SARAN}

\section{Simpulan}

Penelitian ini menunjukkan hipotesis diterima bahwa Pengetahuan Anggota Dewan tentang Anggaran dan Persepsi Anggota Dewan tentang Partisipasi Masyarakat berpengaruh terhadap Pengawasan APBD, baik diuji secara parsial maupun simultan.

\section{Saran}

Peneliti selanjutnya agar dapat lebih mengembangkan penelitian ini dengan meneliti faktor lain yang dapat mempengaruhi Pengawasan APBD, misalnya: Transparansi Kebijakan Publik dan Akuntabilitas Publik, sehingga akan semakin mendalam lagi jika ada faktor lain 


\section{JURNAL NOMINAL / VOLUME VIII NOMOR 2 / TAHUN 2019}

yang dapat memengaruhi Pengawasan APBD.

Bagi Anggota Dewan Pemerintah Kabupaten Klaten, sebaiknya untuk meningkatkan pengetahuan atas penyusunan anggaran dengan cara mengikuti pendidikan dan pelatihan yang dilaksanakan Kemendagri dan membuat program kegiatan sosialisasi secara terstruktur dan terjadwalkan, sehingga menjadi agenda wajib yang harus diikuti para anggota dewan.

\section{DAFTAR PUATAKA}

Achmadi, dkk, (2002), Good governance dan Penguatan Institusi Daerah, Masyarakat Transparansi Indonesia, Jakarta.

Devi, Yulinda $\mathrm{P}$ dan Andriyani, Lilik. (2010). Determinasi Hubungan Pengetahuan Dewan Tentang Anggaran dengan Pengawasan Dewan pada Keuangan Daerah (APBD) (Studi Empiris pada DPRD se-Karisidenan Kedu). Simposium Nasional Akuntansi XIII. Purwokerto.

Kasus Persepsi Anggota Dewan dan Pengembalian Dana APBD di akses pada Kamis, 11 Juli (2019) di http://suaramerdeka.com

Mardiasmo. (2002). Akuntansi Sektor Publik. Yogyakarta: Andi.

Panuntun Bagus Amin, (2012), Pengaruh Partisipasi Masyarakat Dan Pengetahuan Dewan Tentang Anggaran Terhadap Pengawasan APBD (Studi Empiris Pada DPRD Kabupaten Klaten Jawa Tengah).Skripsi Fakultas Ekonomi Jurusan Akuntansi Universitas Muhammadiyah Surakarta.

Sopanah, (2003). Pengaruh Partsipasi Masyarakat Terhadap Hubungan Antara Pengetahuan Dewan Tentang Anggaran Dengan Pengawasan Keuangan Daerah, Makalah Symposium Nasional Akuntansi V, Semarang.
Sopanah. (2009). Studi Fenomenologis: Menguak Partisipasi Masyarakat Dalam Proses Penyusunan APBD. SNA XII

Sugiyono. (2016). Metode Penelitian dan Pengembangan $R \& D$. Bandung : Alfabeta.

Winarna, Jaka, dan Sri Murni. (2006). Pengaruh Personal Background, Political Background dan Pengetahuan Dewan tentang Anggaran terhadap Peran DPRD dalam Pengawasan Keuangan Daerah. Simposium Nasional Akuntansi X. Makasar.

Yudhoyono, Bambang, (2002), Optimalisasi Peran DPRD dalam Penyelenggaraan pemerintahDaerah,http://www.bang da.depdagri.go.id/jurnal/jendela/jend ela3.htm. 